\title{
Mapping of Pollution Risk of Surface Waters by Runoff from Watershed: Case of Aghien Lagoon (South of Côte d'Ivoire)
}

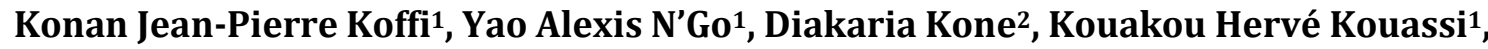 \\ Savané Issiaka ${ }^{1}$ \\ ${ }^{1}$ Laboratory of Geosciences and Environment of University of Nangui Abrogoua, Abidjan, Côte d'Ivoire \\ ${ }^{2}$ Department of Water Resources, National Office of Drinking Water (ONEP), Abidjan, Côte d'Ivoire \\ Email:jipikok@yahoo.fr
}

Received 25 March 2014; accepted 14 December 2015; published 17 December 2015

Copyright (C) 2015 by authors and Scientific Research Publishing Inc.

This work is licensed under the Creative Commons Attribution International License (CC BY).

http://creativecommons.org/licenses/by/4.0/

cc) (†) Open Access

\section{Abstract}

The operating capacity of the Abidjan's groundwater became insufficient. The deficit in drinking water resources in the District of Abidjan remains the major concern of the decision maker. The Aghien lagoon stands as one of the most interesting alternatives. However, studies show the levels of pollutions of this resource without lighting out on the causes and sources of these pollutions. The present study extends over the entire catchment of the Aghien lagoon which reveals the presence of urban areas and agricultural activity areas. This raises real concerns for the Ivorian authorities. This study suggests making cartography of the risk levels of pollution on the Aghien lagoon by the surface runoff on the watershed to enlighten the decision-makers on the possible measures to be taken for the protection of this resource. It emerges from it that the risk of contamination of the lagoon is very likely. Agricultural and domestic best practices inside the pouring pond are compulsory to fight against the pollutions of this resource.

\section{Keywords}

Pollution Risk, Watershed, GIS, Aghien Lagoon, Abidjan

\section{Introduction}

Abidjan is currently fed out of drinking water exclusively starting from the quaternary groundwater. This resource is increasingly insufficient because of the demographic pressure. It is moreover, under the threat of contamination by sources of organics and chemical pollution [1]-[6]. The recourse to other sources of water to sa- 
tisfy the pressing requirements of water for the town of Abidjan is increasingly urgent. To palliate this insufficiency, it is question of resorting to sources such as surface water of the lake Bakré, the Aghien lagoon and the Comoé River and the groundwater of the continental terminal of Bonoua. The Aghien lagoon, subject of this study, was the object of several researches which was limited to physicochemical, quality [7] and bathymetry. These studies concluded that the Aghien lagoon is prone to chemical and bacteriological pollution. However, it remains eligible for exploitation for reinforcement of the drinking water capacity of the district of Abidjan. Lagoon Aghien, in this study, has its catchment in urban areas and areas of agricultural activity that could affect the water quality of this resource. Indeed [8]-[14] showed that any activity conducted or carried on the water shed influence the water surface. The objective of this study is to mapping and to prioritize the risk levels of pollution of the Aghien lagoon by the surface runoff in order to inform the decision makers on the possible provisions to take for the protection of this resource. This Mapping requires the identification, the evaluation and the crossing in an interface of SIG of the factors which contribute to this risk

\section{The Study Area}

The spatialization of the risk requires the geographical definition of entity in which the risk will be calculated [15]. The study area is the watershed of Aghien lagoon. It is located at the South of the Ivory Coast, in the District of Abidjan between coordinates 378,000 and 408,000 m Est and coordinates 595,000 and 620,000 m Nord (UTM 30). It covers an area of $361 \mathrm{~km}^{2}$ and a perimeter of 92.8 kilometers for compactness index Kc $=1.37$. It contains a part of the city of Abidjan, Common Bingerville and Anyama. Aghien lagoon has an area of $20 \mathrm{~km}^{2}$ for a perimeter of $40.72 \mathrm{~km}$ and an estimated volume of $0.113 \mathrm{~km}^{3}$ [16]. It is part of the Abidjan lagoon network. It is powered by two major tributaries such as the Djibiand Bete (Figure 1).

\section{Materiel, Data and Methods}

\subsection{Materials and Data}

The contact between the lagoon and the whole watershed is done by hydrological phenomena of surface depending on morphology on the landscape [17] and a careful representation of the hydrological processes is

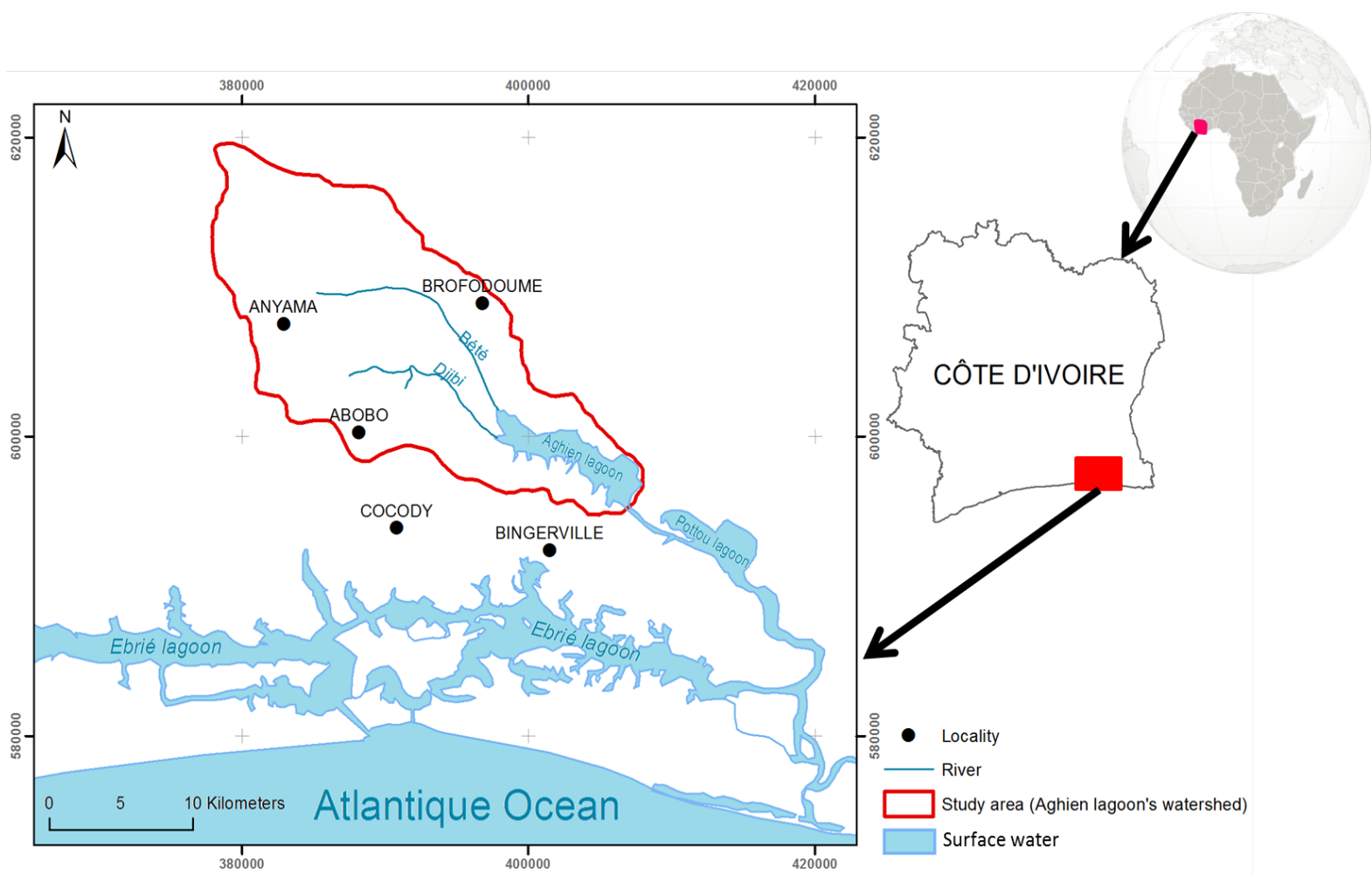

Figure 1. Location map of the study area. 
necessary for the hydrologic modeling as it promises better estimates of hydrologic variables for management decisions [18]. The data used in this study is the DEM of the Ivory Coast of 90 meter resolution. To this data are added the Quick-bird image of 0.6 meter resolution taken September 30, 2009 and the map of land used from August 9, 2010 to the 1/200,000 provided by the cartography and remote sensing center of the Ivorian office of technical studies and development (BNETD). Finally the Google Earth image of April 10th, 2013 covering the study area.

These data were treated with a set of software that Envi 4.5, Grass 6.4.3 svn and ArcGis 10. Equipment for the validation of the land use map is constituted of a Global Position System (GPS) and a digital camera.

\subsection{Methods}

Among the possible risk factors of pollution, appear of the unfavorable interactions between the practices of land use (pressure) and the pedoclimatic conditions and topography of physical environment (vulnerability) [19].

\subsubsection{Vulnerability}

The calculation of the vulnerability to the surface water pollution passes by the identification and the evaluation of the mechanisms likely to bring these molecules since the source to surface water [9] [20] [21]. If one excludes the transfer by air, the only vector of pollutants transport is water. It is advisable to study the mechanism of water circulation of. This circulation will be studied from the time point of view of transport since the sources to the target (Aghien lagoon). The choice of this parameter corresponds to the assumption adopted by [22] which stipulates that a long time of transfer is supposed to increase the potentialities of degradation by detoxification and increases dilution. The determination of the travel time of water to the lagoon was done using the hydrological analysis method developed by [23]. This method was developed by [24]. Indeed, in addition to form studies correction factor is introduced because the calculation of flow velocities has assume year equilibrium discharge which accounts for a rainfall duration equal to or greater than the time of concentration. This assumption often results in channel flow velocities biased towards large values. The map of the water travel time was recodified in terms of vulnerability going from 1 to 5 (Table 1 ).

\subsubsection{Polluting Pressures}

The polluting pressures (hazard of pollution) are defined as the whole practices likely to involve pollution [25]. It is here about practices which can induce the pollution of the lagoon. These pressures are identified through the land use analysis of the feed watershed of the lagoon [17]. The challenge here it is the safeguarding of the water quality of the Aghien lagoon. The land use map acquired with the CCT was brought update by digitalization with ArcGis 10 of the new elements of the landscape recognized on the Google Earth image. The hierarchisation of the pressure levels is founded on the land use analysis, the agricultural activities, the nature and the managing mode of the domestic rejections. The map of land use was then recodified in terms of pressure level going from 1 to 5 (Table 2).

\subsubsection{The Risk}

The risk of pollution of the lagoon is linked to its vulnerability and the pressures on it. According to [26], the cartography of a risk, for a pollutant or a family of pollutants, requires the crossing of:

- a map of the challenge's vulnerability,

- and a map of the risks on the challenge.

Table 1. Codification of the vulnerability according to travel time.

\begin{tabular}{|c|c|c|}
\hline Travel time (hours) & Level of vulnerability & Code \\
\hline More than $48 \mathrm{~h}$ & Very low & 1 \\
\hline $36 \mathrm{~h}-48 \mathrm{~h}$ & Low & 2 \\
\hline $24 \mathrm{~h}-36 \mathrm{~h}$ & Moderate & 3 \\
\hline $12 \mathrm{~h}-24 \mathrm{~h}$ & High & 4 \\
\hline Less than $12 \mathrm{~h}$ & Very high & 5 \\
\hline
\end{tabular}


The GIS offer a better approach to estimate and to map the probability that the Aghien lagoon be polluted using a simple model. The GIS in this work is conceived by ArcGis 10. The recombination of the pressure and the vulnerability lead to calculate and spatialize the level of pollution risk on the lagoon. It is performed by the following equation:

$$
\text { RISK }=\text { PRESSURE } \times \text { VULNERABILITY }
$$

The index obtained is coded according to five (5) level of risk. The diagram below summarizes the method for calculation the pollution risk on Aghien lagoon (Figure 2).

\section{Results}

\subsection{The Pressure}

To understand the landscape and to deduce the sources of pollution (pressures), we realized the map of land use of the watershed (Figure 3).

This map shows eleven (11) types of land use such as the cultures of banana (6\%), of oil palm tree (2\%), about hevea (2\%), the human establishments (15\%), the dense forests (3\%) and degraded forests (8\%), swamps or mangrove swamps $(2 \%)$, waterlogged areas $(1 \%)$, surfaces of wastewaters $(2 \%)$ and the surfaces of water $(6 \%)$.

The field visits inform about the phytosanitary treatments in the industrial plantations, the inappropriate evacuation of household waste and wastewater resulting from the urban area. Banana plantations upstream to the study area, the plantations of oil palm trees and rubber plantation in the North of the Aghien lagoon are identified as sources of pollution. Populations of villages in border of the lagoon use this lagoon as natural dump for reject there household waste. All these observations allowed recodifying the map of the land use in map of pressure (Figure 4). This map shows that the very strong pressures represent $1.7 \%$ of the surface of the pond

\section{Table 2. Codification of the pressure according to land use.}

\begin{tabular}{ccc}
\hline Type of land use & Levels of pressure & Code \\
\hline $\begin{array}{c}\text { Dense forest } \\
\text { Swamp forest, mangrove swamp } \\
\text { waterlogged areas } \\
\text { Degraded forest } \\
\text { culture or fallow } \\
\text { Industrial plantation }\end{array}$ & Very low & 1 \\
Human installing & Low & 2 \\
Wastewater & Moderate & 3 \\
\hline
\end{tabular}

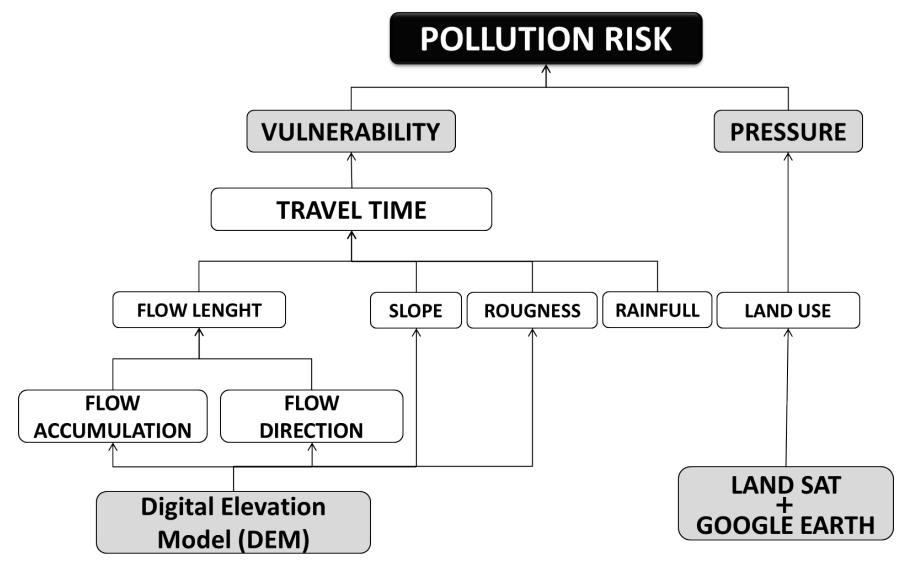

Figure 2. Methodology for calculation the pollution risk on Aghien lagoon. 
K. J.-P. Koffi et al.

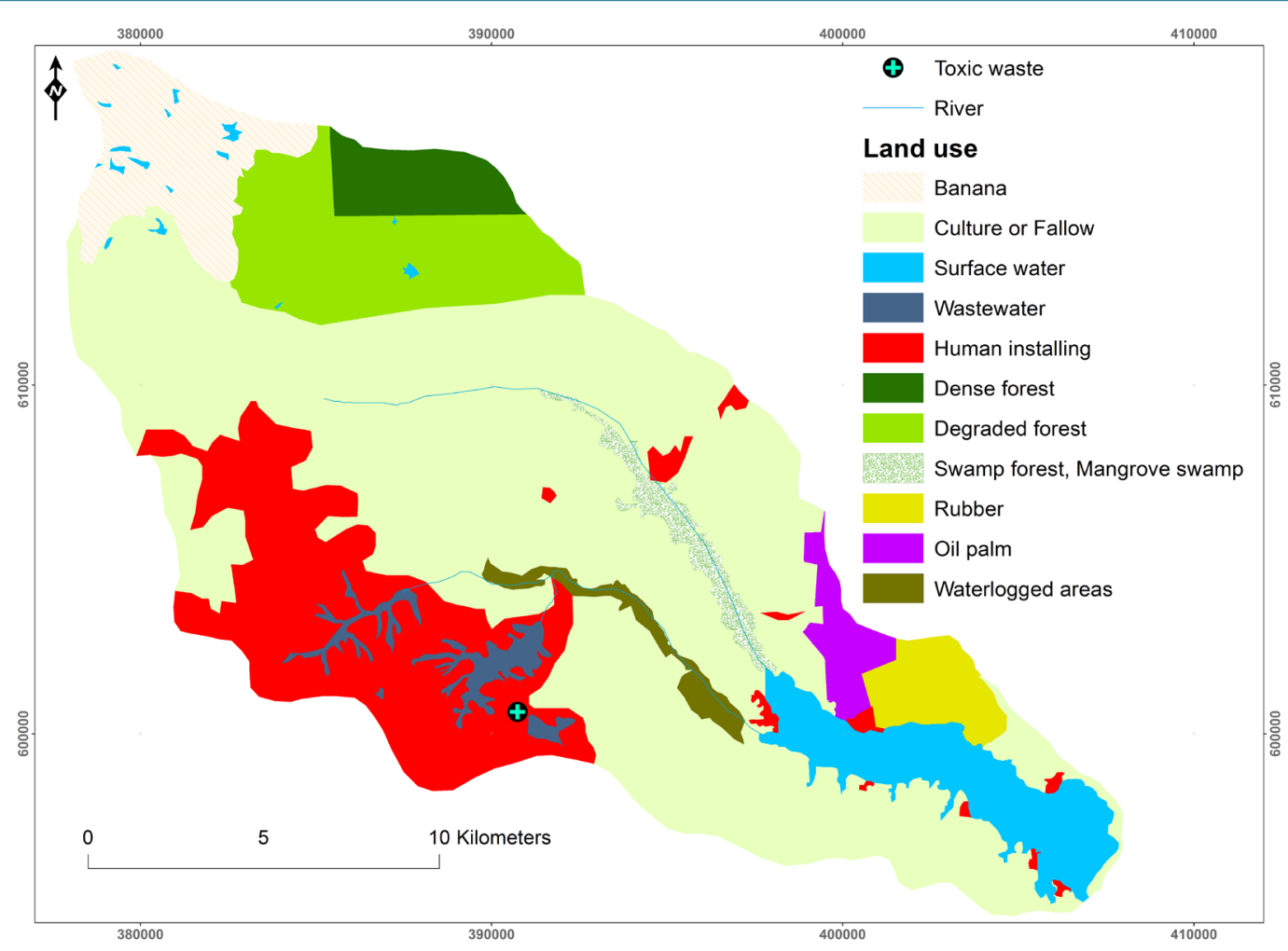

Figure 3. Map of land use.

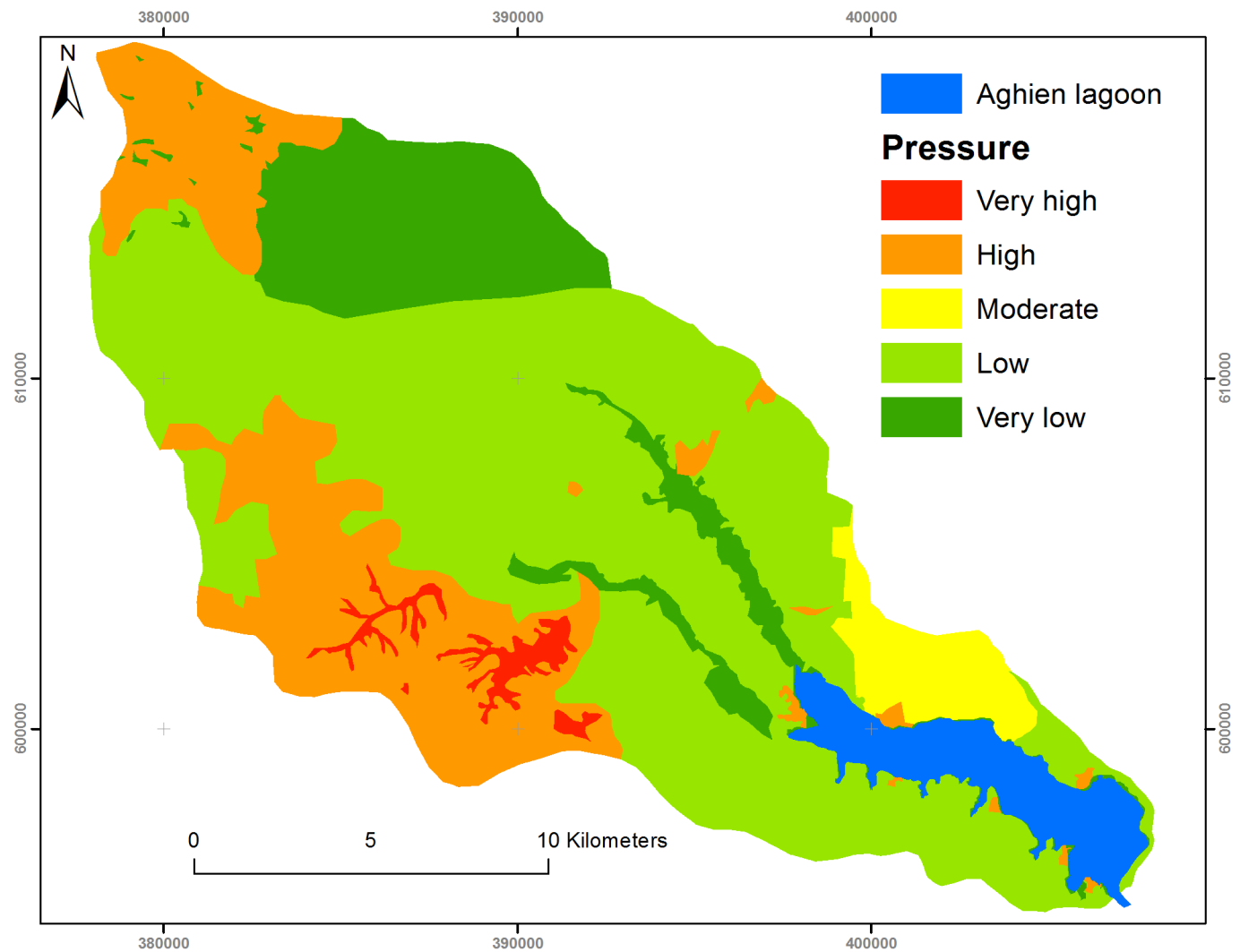

Figure 4. Pressures map. 
and are located in the zones of concentration of wastewater of surface of the municipality of Abobo. The strong pressures $(21.1 \%)$ are mainly urban areas and banana plantations upstream of study area. The moderate pressures $(4 \%)$ occupy the areas of the rubber plantation and oil palm in the North of the lagoon. As for the low pressures (53.4\%), they cover the median zone of the study area and the South of the lagoon Aghien. Finally, the very low pressures (14.6\%) are located in hydromorphic areas around the bed of the main stream (Bété and Djibi) and vegetation zones in the North of study area.

\subsection{Vulnerability (Distance to Lagoon)}

The vulnerability map of the Aghien lagoon to the pollution by surface runoff (Figure 6) is obtained from the travel time map of surface runoff to the lagoon (Figure 5). This travel time map shows that it increases gradually as we move away from the lagoon but no proportionally. It is due to the fact that the travel of surface runoff is a morpho-hydrological process. That is the water circulates in the depressions of the watershed and does not follow a right path to the lagoon.

Five (5) levels of vulnerability of the lagoon towards the pollutions by to the surface runoff are defined. The vulnerability follows the same logic as the travel times. It is high when we are near the lagoon and decrease gradually when we move away from the lagoon. This estrangement is not a linear distance to the lagoon but a hydrological distance which takes into account the runoff path, the roughness and the slope of the landscape.

\subsection{Cartography of Pollution Des Risk}

The map of risks pollution of the lagoon (Figure 7) defines 5 levels of risk. The very high risks represent $0.8 \%$ of the total surface of the watershed. They are located at the villages in border of the lagoon and in the center of the concentration zones of domestic wastewater. The high risks (7.4\%) are similar to the concentration zones of wastewater of the municipality of Abobo. The plantations of oil palm and rubber plantation in the North of the Aghien lagoon are also considered as high risk zones of contamination of the lagoon. The zones of moderate risk (43.3\%) dominate the rest of southern half of the watershed. As for the low risk (32.7\%) and very low risk $(10.5 \%)$, hey dominate the upstream of watershed. They correspond to zones that are sufficiently distant from the lagoon Aghien.

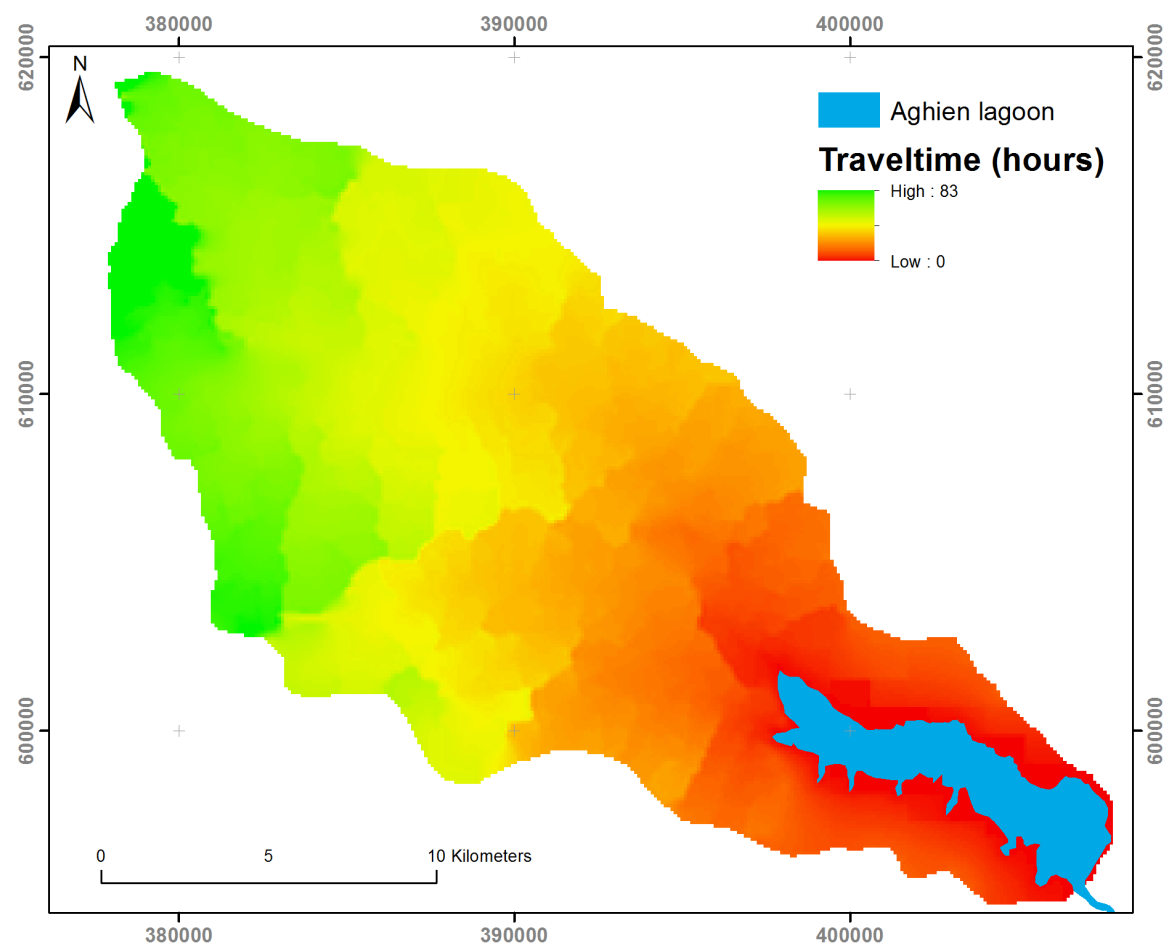

Figure 5. Travel time map. 


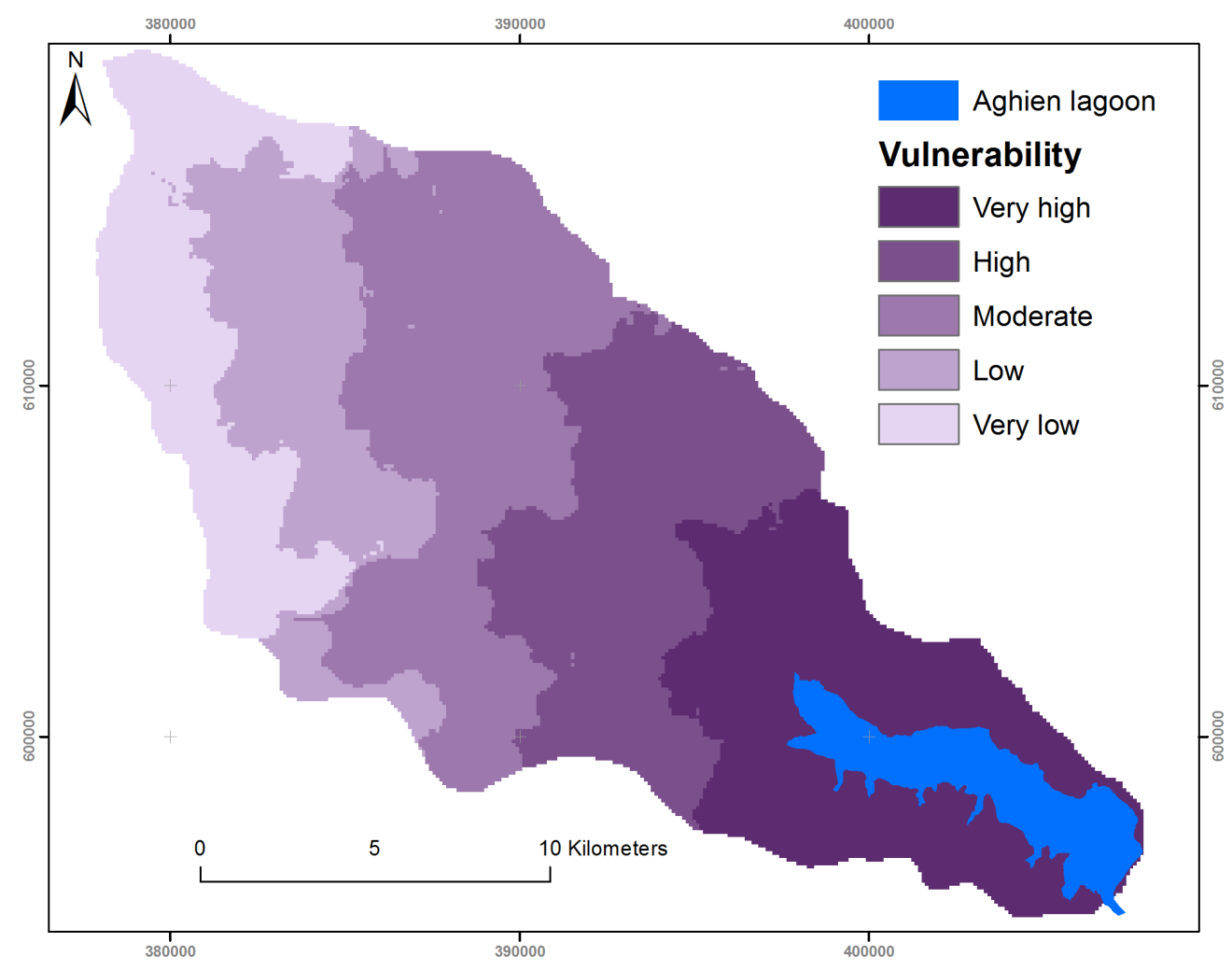

Figure 6. Vulnerability map according travel time.

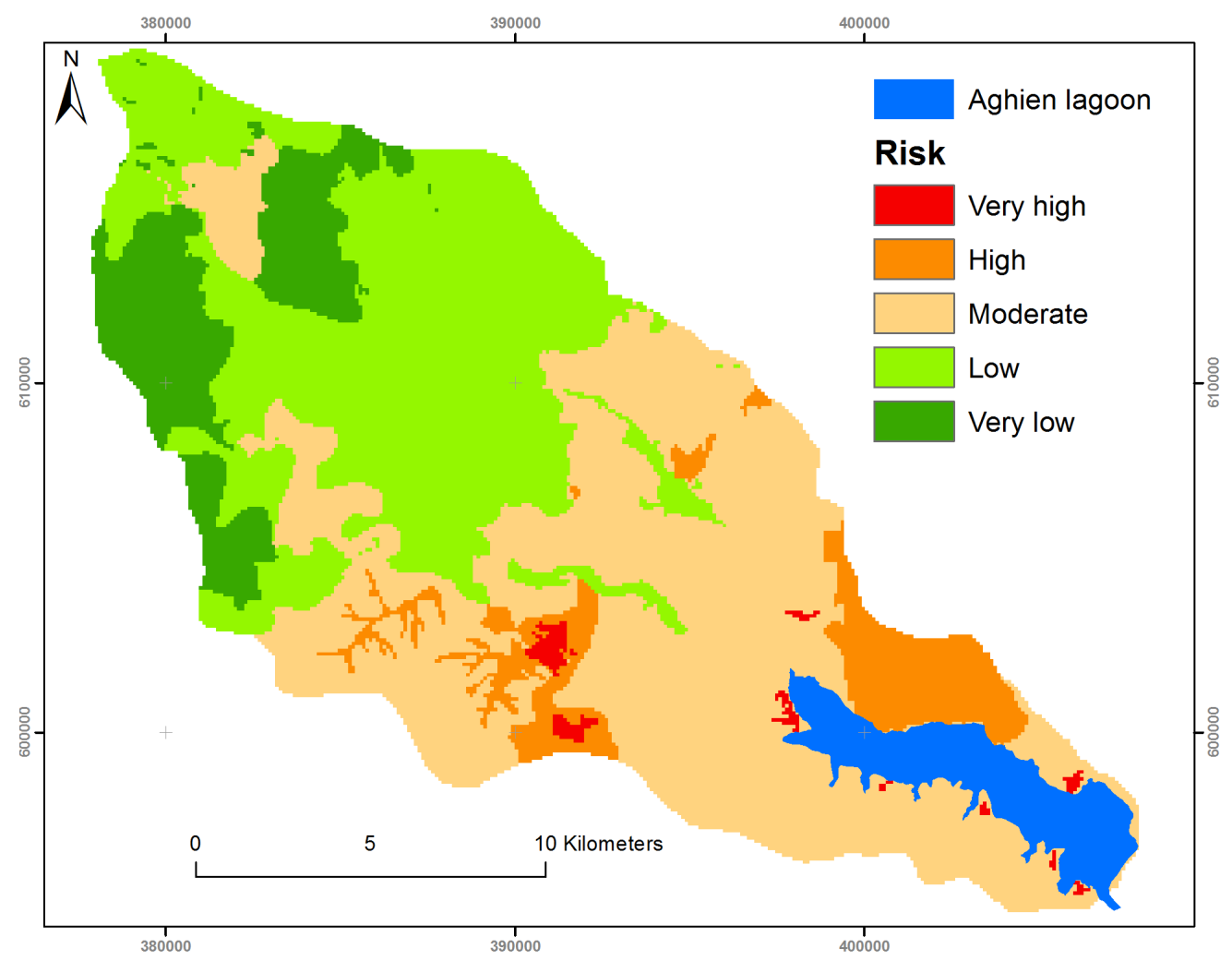

Figure 7. Map of pollution risk. 


\section{Discussion}

The concern to enlighten the decision-makers on measures to be taken for the protection of the Aghien lagoon led us to mapping and to prioritize the pollution risk levels of this resource. According to the map of the pollution risks, the contamination of the lagoon is very likely if urgent measures are not taken by the decision-maker. The high risks correspond to the zones of habitats near the lagoon and in the concentration zones of domestic wastewater in the municipality of Abobo, Abidjan suburb.

These zones should be the object of urgent measures to lower the level of pollution risk which is due to the proximity of pollution sources towards the lagoon. The risks observed far from the lagoon concern the zones of high anthropological pressures. This contamination can make by phytosanitary products (pesticides and fertilizers) applied in industrial plantations of the watershed. This risk can be also due to wastewater resulting from the municipality of Abobo.

As suggests [27], this prioritization takes into account of detoxification phenomena due to the distance, better, to the travel time of the pollutant to the target which is here Aghien lagoon. It is what explains that the low risks are mainly far from the lagoon. The mapping method of the risk levels allows a prioritization of the pollution risk of the Aghien lagoon according to the vulnerability and the polluting pressure. This method is indicative and offers the possibility of targeting the priority zones for an intervention [25]. Various methods exist to estimate the pollution risk of surfaces water. For example, [15] used rather the chemical and biological parameters for evaluation of the pollution risk. However the spatial approach by the GIS offers an easy intervention for the decision-maker [19]. Otherwise, the possible water pollution is also influenced by phenomena of molecules retention on the soil particles, and degradation.

This method does not heed the risk assessment of the degradation of phytosanitary products which takes place mainly according to processes of detoxification that are complex and difficult to measure [27]. To manage the risks, it is necessary to define a sharp legislative framework and technical recommendations. For that purpose, the application decree of the code of the water in yard of elaboration will have to contain key elements of the protection of water resources. He will also have to specify technical requirements concerning the perimeters of protection.

\section{Conclusion}

This study involved the assessment of risks of pollution of the lagoon Aghien with a GIS. This GIS helped to know the pressures sustained by the lagoon, her vulnerability and the risk of pollution. The eligibility of the lagoon in exploitation for production of drinking water for the district of Abidjan is may be threatened because of the risks of pollution on the watershed. The spatialization of its risks thanks to the GIS offers the possibility to target the priority zones for an intervention. Urgent measures should be taken to insure this eligibility. Among others measures, the implementation of supervisory committee and updated data collection on the land use could contribute to improve the results. So it is necessary to approach this study in the parcel scale to understand closely the leaks of pollutants for mapping of their sources. Finally a chemical study on the whole watershed accompanied with a biological study of the Aghien lagoon would contribute to the improvement of the knowledge on this resource.

\section{References}

[1] Ahoussi, K.E., Soro, N., Soro, G., Lasm, T., Oga, M.S. and Zade, S. (2008) Groundwater Pollution in Africans Biggest Towns: Case of the Town of Abidjan (Côte d'Ivoire). European Journal of Scientific Research, 20, 302-316.

[2] Jourda, J.P., Kouamé, K.J., Salay, M.B., Kouadio, B.H., Oga, Y.S. and Deh, S. (2006) Contamination of the Abidjan Aquifer by Sewage: An Assessment of Extent and Strategies for Protection. In: Xu, Y.X. and Usher, B., Eds., Groundwater Pollution in Africa, Taylor \& Francis/Balkema, The Netherlands, 291-300.

[3] Kouadio, D.L., Traore, K.S., Bekro, Y.A., Mambo, V., Ardjouma, D., Mamadou, K., Mazellier, P., Legube, B. and Houenou, P. (2009) Contamination des Eaux de Surface par les Produits Pharmaceutiques en Zones Urbaines de Côte D’ivoire: Cas du District d’Abidjan. European Journal of Scientific Research, 27, 140-151.

[4] Kouamé, K., Jourda, J.-P., Leblanc, Y., Deh, S., Anani, A. and Biémi, J. (2009) Implication of Hydrogeologic Modeling in the Estimate of Pollutants Transfer Time Towards Groundwater of Abidjan District: Case of Toxic Waste. European Journal of Scientific Research, 32, 6-24. 
[5] Oga, M.S. (1998) Ressources en eaux souterraines dans la région du Grand Abidjan (Côte d'Ivoire): Approche Hydrochimique et Isotopique. Thèse de Doctorat de l’Université de Paris Orsay, Paris, 240 p.

[6] Traore, K.S., Mamadou, K., Dembele, A., Lafrance, P., Mazellier, P. and Houenou, P. (2006) Contamination de l'eau souterraine par les pesticides en régions agricoles en Côte d'Ivoire. Journal Africain des Sciences de l'Environnement, 1, 1-9.

[7] Traore, A., Soro, G., Kouadio, E.K., Bamba, B.S., Oga, M.S., Soro, N. and Jean Biemi, J. (2012) Évaluation des paramètres physiques, chimiques et bactériologiques des eaux d’une lagune tropicale en période d'étiage: La lagune Aghien (Côte d'Ivoire). International Journal of Biological and Chemical Sciences, 6, 7048-7058.

[8] Belghiti, L., Chahlaoui, A., Bengoumi, D. and El Moustaine, R. (2014) Effect of Anthropic Activities on the Quality of Subsoil Waters in Rural Medium in the Area of Meknes (MOROCCO). Larhyss Journal, 17, 77-89.

[9] El Ouali Lalami, A., Merzouki, M., El Hillali, O., Maniar, S. and Koraichi, I. (2014) Pollution des eaux de surface de la ville de Fes au Maroc: Typologie, origine et conséquences. Larhyss Journal, 9, 55-72.

[10] Macary, F., Maud, B., Puech, C. and Saudubray, F. (2007) Méthode d’estimation d’un risque potentiel spatialisé de la contamination des eaux de surface par les intrants agricoles à différentes échelles spatiales. Application sur les coteaux de Gascogne. Colloque international de Géomatique et d'analyse spatiale, Clermont Ferrand, 18-19-20 Juin 2007, 19 p. http://cemadoc.irstea.fr/cemoa/PUB00021862

[11] MATE, Ministère de l'Aménagement du Territoire et de l’Environnement (2001) Textes relatifs à la prévention des risques naturels majeurs. Recueil des textes fondateurs, 1ère édition, DPPR-SDPRM, 155 p.

[12] N’guessan, K.A., Kouassiamani, M., Gnaboa, R., Traoré, K.S. and Houenou, P.V. (2014) Analyse de phénomènes hydrologiques dans un bassin versant urbanisé: Cas de la ville de Yamoussoukro (centre de la Côte d'Ivoire). Larhyss Journal, 17, 135-154.

[13] Scheren, P.A.G.M., Kroeze, C., Janssen, F.J.J.G., Hordijk, L. and Ptasinski, K.J. (2004) Integrated Water Pollution Assessment of the Ebrie Lagoon, Ivory Coast, West Africa. Journal of Marine Systems, 44, 1-17. http://dx.doi.org/10.1016/j.jmarsys.2003.08.002

[14] Syndicat Mixte des Territoires de Chalaronne (2007) Etude des pollutions diffuses des eaux superficielles par les produits phytosanitaires. Rapport final, $167 \mathrm{p}$.

[15] Ferronato, C., Modesto, M., Stefanini, I., Vianello, G., Biavati, B. and Antisari, L.V. (2013) Chemical and Microbiological Parameters in Fresh Water and Sediments to Evaluate the Pollution Risk in the Reno River Watershed (North Italy). Journal of Water Resource and Protection, 5, 458-468. http://dx.doi.org/10.4236/jwarp.2013.54045

[16] Durand, J.R. and Guiral, D. (1994) Hydroclimat et hydrochimie. In: Durand, J.R., Ecoutin, J.M. and Arfi, R., Eds., Environnement et ressources aquatiques de Côte d'Ivoire, ORSTOM Editions, Paris, 59-92.

[17] Rosi, S., Stamm, C. and Reichert, P. (2009) Modeling Potential Herbicide Loss to Surface Waters on the Swiss Plateau. Journal of Environmental Management, 91, 290-302. http://dx.doi.org/10.1016/j.jenvman.2009.08.019

[18] Venkata, R.K., Eldho, T.I. and Rao, E.P. (2009) A Diffusion Wave Based Integrated FEM-GIS Model for Runoff Simulation of Small Watersheds. Journal of Water Resource and Protection (JWARP), 1, 391-399. http://dx.doi.org/10.4236/jwarp.2009.16047

[19] De la Torre, A., Iglesias, I., Camuñas, L.M., Muñoz, M.J. and Carballo, M. (2013) Comparison of a Soil Vulnerability Map for Tetracycline Soil Contamination at a Global and Local Scale. Journal of Environmental Protection (JEP), 4, 595-601. http://dx.doi.org/10.4236/jep.2013.46069

[20] Carlson, R.E. (1977) A Trophic State Index for Lakes. Limnology and Oceanography, 22, 361-369. http://dx.doi.org/10.4319/lo.1977.22.2.0361

[21] Colin, F. (2000) Approche spatiale de la pollution chronique des eaux de surface par les produits phytosanitaires. Thèse ENGREF, Cas de l'atrazine dans le bassin versant du Sousson (Gers, France), 152 p.

[22] Collectif (2001) Localisation des zones à risque vis-à-vis du transfert des substances phytosanitaires vers les eaux superficielles et souteraines en Midi-Pyrénées; méthode de travail. Rapport commun RGM-CRAMP-DIREN-DRAF/ SRPV-Fredec.

[23] Förster, K. (2007) GRASS Raster Program “r.traveltime”. http://jesbergwetter.twoday.net/stories/4845555/

[24] Melesse, A.M. and Graham, W.D. (2004) Storm Runoff Prediction Based on a Spatially Distributed Travel Time Method Utilizing Remote Sensing and GIS. Journal of the American Water Resources Association, 8, 863-879. http://dx.doi.org/10.1111/j.1752-1688.2004.tb01051.x

[25] Christine, T. (2001) Diagnostic du risque de pollution des eaux superficielles par les produits phytosanitaires: Typologie des bassins versants du beaujolais viticole. Mémoire de fin d’études. Ingénieur des Techniques Agricoles, Ecole Nationale d’Ingénieurs des Travaux Agricoles de BORDEAUX.

[26] Allier, D., Pinson, S. and Leclerc, B. (2010) Caractérisation de la vulnérabilité et des risques de pollution des sources 
de Martinique. BRGM/RP-58105-FR, 92 p.

[27] Gouy, V., et al. (1996) Etude du transfert des produits phytosanitaires sur les bassins versants et modélisation. Actes du séminaire national: Produits phytosanitaires, processus de transfert et modélisation dans les bassins versants, Nancy. CEMAGREF éditions, 89-103. 